\title{
Knowledge Capture Menggunakan Teknik Explore, Elaborate dan Execute Untuk Bagian Kesiswaan Sekolah
}

\author{
Victor Peter Lodewyk Duan ${ }^{1 *}$, Danny Manongga ${ }^{2}$, Ade Iriani $^{3}$ \\ 1,2,3 Jurusan Sistem Informasi, Fakultas Teknologi Informasi, Universitas Kristen Satya Wacana, Salatiga \\ ${ }_{1,2,3} \mathrm{~J}$ In. Dr. O. Notohamidjojo, Kota Salatiga, 50715, Indonesia \\ email: ${ }^{1}$ victorlodewyk@gmail.com, ${ }^{2}$ dmanongga @gmail.com, ${ }^{3}$ adeiriani@gmail.com
}

\author{
Received: 25 Juli 2018; Revised: 1 Oktober 2018; Accepted: 4 Oktober 2018 \\ Copyright $\odot 2018$, Politeknik Harapan Bersama, Tegal
}

\begin{abstract}
Students are late to school showed a lack of awareness about discipline. The teachers who handle the student late are created the tacit knowledge. This paper applied explore, elaborate and execute technique to capture the knowledge. The purpose is to documenting and stored it as a wealth of school knowledge by create a model in knowledge capture. The model of knowledge capture can be an indicator in capturing and documenting knowledge process so it will be good impact when handling the students late. The result showed the model of knowledge capture was created based on three step explore, elaborate and execute with the factors who cause students late. The use of technology have not technofull applicable in process to capturing knowledge except in documenting and storage process, allow to presence a utilization technology design in capturing knowledge on future research.
\end{abstract}

\begin{abstract}
Abstrak - Siswa terlambat ke sekolah menunjukan masih kurangnya kesadaran siswa tentang kedisiplinan. Guru-guru yang menangani siswa terlambat telah menciptakan pengetahuan yang masih bersifat tacit. Penelitian ini dilakukan untuk menangkap pengetahuan dengan menerapkan teknik explore, elaborate dan execute. Tujuannya agar pengetahuan yang dimiliki bisa terdokumentasi dan tersimpan sebagai kekayaan pengetahuan sekolah dengan memodelkannya dalam model knowledge capture. Pemodelan penangkapan pengetahuan di sekolah dapat menjadi indikator proses penangkapan dan pendokumentasian pengetahuan sehingga bisa berdampak baik pada kelola kasus siswa terlambat. Hasil menunjukan telah terciptanya model knowledge capture berdasarkan tiga langkah tindak explore, elaborate dan execute yang menunjukan adanya faktor-faktor yang menyebabkan keterlambatan siswa. Proses penangkapan pengetahuan belum memanfaatkan teknologi sepenuhnya kecuali pada proses penyimpanan dan dokumentasi, memungkinkan adanya sebuah desain pemanfaatan teknologi untuk menangkap pengetahuan guru di sekolah pada penelitian selanjutnya.
\end{abstract}

Kata Kunci - Knowledge Capture, Knowledge Management, Explore, Elaborate, Execute

\section{PENDAHULUAN}

Lembaga pendidikan formal dalam hal ini Sekolah Menengah Atas memiliki siswa sebagai peserta didik untuk

*) Corresponding Author: (Victor Peter Lodewyk Duan)

Email: victorlodewyk@gmail.com mendukung penyelenggaraan pendidikan. Seperti yang tertulis dalam Undang-Undang Nomor 20 tahun 2003 tentang sistem pendidikan nasional bahwa pendidikan adalah usaha sadar dan terencana untuk mewujudkan suasana belajar dan proses pembelajaran agar peserta didik secara aktif mengembangkan potensi dirinya untuk memiliki kekuatan spiritual keagamaan, pengendalian diri, kepribadian, kecerdasan, akhlak mulia, serta keterampilan yang diperlukan dirinya, masyarakat, bangsa dan negara [1]. Supaya lebih tertata dan terstruktur, penyelenggaraan pendidikan yang dilaksanakan harus memiliki aturan-aturan tertentu yang dikenal dengan nama Tata Tertib Sekolah. Perilaku, aturan dan tata tertib dikelompokan menjadi dua yaitu 1) kepatuhan dan ketaatan siswa terhadap peraturan sekolah yang disebut disiplin siswa dan 2) peraturan dan berbagai tata tertib yang mengatur perilaku siswa disebut disiplin sekolah [2].

Banyaknya siswa yang dimiliki SMA Kristen Tobelo Kab. Halmahera Utara tidak terlepas dari banyaknya pelanggaran yang dilakukan para siswa melanggar aturan-aturan yang telah dibuat oleh sekolah. Hal ini menjadi sebuah masalah karena bertolak belakang dengan tujuan dan misi sekolah dimana sekolah sebagai sebuah lembaga pendidikan yang ingin meningkatkan mutu dan kualitas harus bisa mendidik dan mengajarkan hal-hal baik kepada para siswa. Banyak dan beragamnya pelanggaran yang dilakukan oleh siswa-siswa menjadi penting untuk bisa dikelola. Sehingga banyak sedikitnya pelanggaran yang dilakukan tergantung dari bagaimana sekolah mengelolanya. Oleh karena itu, sekolah khususnya guru harus bisa mengarahkan siswa ke hal-hal yang baik. Siswa yang melakukan pelanggaran adalah siswa yang secara sadar, sengaja atau tidak sengaja telah melakukan tindakan yang dilarang oleh sekolah dan akan dikenakan sanksi. Terdapat beberapa pelanggaran-pelanggaran yang banyak dilakukan para siswa diantaranya terlambat datang ke sekolah, atribut dan pakaian tidak sesuai dan tidak lengkap, alpa dan bolos sekolah. Diantara pelanggaran-pelanggaran yang telah disebutkan, tingkat pelanggaran tertinggi yang paling sering terjadi adalah siswa terlambat ke sekolah. Terlambat datang ke sekolah menunjukan masih kurangnya kesadaran siswa tentang kedisiplinan. Kedisiplinan pada siswa sangat penting diperhatikan. Belajar merupakan suatu kegiatan untuk mengadakan perubahan didalam diri seseorang yaitu: perubahan tingkah laku, sikap, kebiasaan, ilmu pengetahuan dan sebagainya. Perubahan-perubahan ini 
merupakan perbuatan belajar yang diinginkan, kerena itu dapat dikatakan bahwa perubahan yang diinginkan akan menjadi tujuan dari proses pembelajaran [3]. Sekolah harus mempunyai peraturan-peraturan yang mengatur tentang keterlambatan siswa ke sekolah beserta dengan konsekuensi jika dilanggar, guru juga berperan penting dalam ketegasan dan mendidik siswa untuk disiplin. Dalam menangani setiap kasus terlambat ke sekolah, sebagai seorang guru harusnya bisa memahami dan mengerti apa yang menjadi alasan, faktor-faktor yang menyebabkan siswa terlambat ke sekolah dan jangan hanya bisa memberikan sanksi.

Berbagai bentuk penanganan yang dilakukan pihak sekolah pastinya telah banyak ditemui faktor-faktor yang menyebabkan siswa terlambat. Dengan demikian berbagai macam pengetahuan muncul didalamnya. Kondisi inilah yang menjadi landasan dari penelitian yang dikerjakan agar pengetahuan-pengetahuan yang tercipta pada proses penanganan pelanggaran siswa diharapkan dapat terdokumentasi sehingga menjadi kekayaan pengetahuan sekolah dan dapat dimanfaatkan. Supaya dapat dimanfaatkan, maka pengetahuan yang muncul dalam organisasi sekolah harus bisa "ditangkap". Untuk bisa menangkapnya diterapkan konsep Knowledge Capture untuk organisasi sekolah.

Pada penelitian ini, teknik explore, elaborate dan execute diterapkan sebagai metode untuk menangkap pengetahuan yang dimiliki para guru di sekolah dalam menangani kasus siswa terlambat. Teknik ini merupakan gabungan dari tiga cara penyelesaian masalah yang digabungkan menjadi satu. Penelitian ini dilakukan dengan tujuan untuk menghasilkan sebuah model knowledge capture yang dapat digunakan untuk menangkap pengetahuan dengan memanfaatkan teknik explore, elaborate dan execute sebagai metode penyelesaian masalah. Tujuan pemodelan penangkapan pengetahuan ini agar dapat menjadi indikator dalam proses penangkapan pengetahuan dan pendokumentasian pengetahuan sehingga berdampak pada penanganan dan pengelolaan kasus siswa terlambat.

\section{PENELITIAN YANG TERKAIT}

Sebuah penelitian terdahulu berbasis Knowledge Capture dilakukan oleh Mark [4] menyajikan sebuah studi kasus bagaimana teknologi wiki diterapkan dalam organisasi untuk mengembangkan "intrapedia" untuk penangkapan pengetahuan organisasi. Pada penelitian ini digabungkan antara intranet dan wikipedia dimana wiki dijadikan sebagai sumber penangkapan pengetahuan dan dibatasi dengan akses hanya dalam organisasi perusahaan (intranet). Wiki yang didefinisikan sebagai sebuah web dinamis dengan konten yang bisa ditambahkan langsung dari pengguna, digunakan untuk menangkap berbagai pengetahuan masyarakat umum. Secara signifikan banyak penelitian tentang wiki difokuskan pada penggunaan "corporate wikis" untuk mendukung aspek seperti e-learning, manajemen proyek, penjadwalan, kolaborasi dan Customer Relationship Management. Dapat dikatakan bahwa wiki menjadi patokan umum utama yang dipelajari untuk menangkap pengetahuan karena beberapa alasan gratis, berbasis web, kolaboratif dan multibahasa. Salah satu penerapan teknologi wiki dalam perusahaan adalah dengan menjadikan wiki sebagai sumber penangkapan pengetahuan organisasi yang lebih dispesifikasikan sebagai "intrapedia".
Penelitian yang dilakukan oleh Anagnostakis, dkk [5] menunjukan adanya kesenjangan besar dalam pemahaman perencanaan strategi CMM (Coordinate Measuring Machines). CCM adalah sebuah cara yang digunakan untuk pengendalian dan mengevaluasi kualitas produk. Permasalahan disini terletak pada kurangnya pengetahuan eksplisit yang tersedia tentang bagaimana proses para ahli menyusun dan melaksanakan perencanaan pengukuran. Hasilnya memberikan gambaran dari sistem evaluasi pemeriksaan, hambatan dan tantangan dari sudut pandang knowledge capture serta menunjukan paradigma baru tentang rekayasa digital yang memiliki potensi untuk memfasilitasi penangkapan pengetahuan.

Mourtzis [6] dalam penelitiannya membuat sebuah sistematika penangkapan pengetahuan dalam perusahaan manufaktur. Mourtzis berpendapat bahwa dalam kegiatan manufaktur terjadi banyak pengulangan dan menghasilkan jumlah data yang sangat banyak yang kurang dimanfaatkan. Terdapat juga kesamaan dengan masa lampau dalam hal desain dan perencanaan proyek yang informasinya dapat dimanfaatkan menjadi pengetahuan antara pekerja, departemen dan mitra perusahaan untuk keaktifan koordinasi masing-masing bagian. Hasil menunjukan kasus yang didasarkan pada model data, komponen dari penggunaan kembali pengetahuan yang diperkaya dengan sekumpulan pengetahuan telah berhasil dinyatakan.

Penelitian oleh Rocca [7] terhadap orang-orang Chamorro yang dalam ancaman kehilangan pengetahuan budaya dan tradisi dari satu generasi ke generasi selanjutnya karena pengaruh budaya barat. Mereka memanfaaatkan informasi dan teknologi komunikasi dalam hal ini sosial media untuk menangkap dan menyampaikan pengetahuan budaya orang chamorro. Dua pengumpulan data yang digunakan adalah jenis pengetahuan budaya Chamorro yang sangat bernilai dan media sosial apa yang digunakan untuk menangkap dan menyampaikan pengetahuan budaya. Hasil menunjukan bahwa sekarang orang-orang Chamorro memanfaatkan teknologi informasi dan komunikasi dalam hal ini sosial media untuk menangkap dan menyampaikan pengetahuan budaya Chamorro.

Penelitian selanjutnya dilakukan oleh Namwel pada tahun 2015 [8] menyelidiki mekanisme penangkapan pengetahuan dan akuisisi pengetahuan di Universitas Kisii. Namun pihak universitas belum banyak mengetahui keunggulan dari penangkapan dan akuisisi pengetahuan yang dapat meningkatkan kinerja organisasi. Sebuah studi kasus dimana data pengetahuan dikumpulkan melalui wawancara dan kuesioner dari responden secara acak. Hasil mengungkapkan ada berbagai mekanisme penangkapan dan akuisisi pengetahuan di Universitas Kisii sehingga peneliti mengusulkan sebuah pedoman yang dapat digunakan oleh universitas untuk meningkatkan kinerja universitas.

Knowledge dapat dipahami sebagai arus informasi diantara sumber daya dalam perusahaan. Penciptaan pengetahuan dimulai dari perubahan yang sinergi antara pengetahuan tacit ke pengetahuan explicit [9]. Arus informasi bisa datang dari pengalaman kerja para pekerja atau dokumentasi fisik, dimana pengetahuan tacit bisa menjadi sangat penting karena sulit diprediksikan dan dinyatakan [10].

Knowledge capture menggambarkan ekstraksi pengetahuan atau pengalaman yang dimiliki seseorang, 
kelompok atau organisasi untuk suatu kepentingan yang sama. Prosesnya meliputi pengidetifikasian, mendapatkan, penyaringan dan penyimpanan pengetahuan untuk disebarkan [11].

Explore (eksplorasi), elaborate (elaborasi) and execute (eksekusi) merupakan beberapa metode yang umum digunakan dalam melakukan sebuah penelitian. Explore yang dalam bahasa indonesia disebut eksplorasi adalah sebuah penjelajahan lapangan dengan tujuan memperoleh pengetahuan lebih banyak (tentang keadaan) terutama sumber-sumber yang terdapat di tempat itu. Elaborasi adalah penggarapan (mengerjakan) sesuatu secara tekun dan cermat dan eksekusi adalah penerapan atau pelaksanaan [12].

Penelitian yang telah dilakukan sebelumnya meneliti tentang knowledge capture pada objek masyarakat sosial, organisasi dan perusahaan dengan menerapkan teknik dan metode yang berbeda-beda. Perbedaannya dengan penelitian ini adalah penelitian ini dilakukan didalam organisasi sekolah menengah atas dengan metode gabungan dari 3 metode yang belum pernah diterapkan bersama untuk menangkap pengetahuan. Dilatar belakangi oleh kebiasaan siswa terlambat ke sekolah dan dalam penanganannya telah menciptakan pengetahuan maka dilakukan penelitian ini untuk membuat model penangkapan pengetahuan.

\section{METODE PENELITIAN}

Penelitian dan penulisan ini menggunakan jenis penelitian kualitatif yaitu proses penelitian dan pemahaman untuk menyelidiki permasalahan yang menghasilkan data terdeskripsi. Metode yang digunakan dalam merancang model Knowledge Capture sekolah adalah dengan cara:

- Explore (selidik)

- Elaborate (uraikan)

- Execute (lakukan)

\section{A. Kerangka Penyelesaian Masalah}

Pemodelan knowledge capture pada SMA Kristen Tobelo Kab. Halmahera Utara untuk bagian kesiswaan yang dibuat akan mengikuti pada metode explore, elaborate, dan execute dengan tambahan beberapa langkah proses untuk penyelesaian masalah yang dibagi dalam dua tahap yaitu:

- Tahap Analisis Studi Kasus

- Tahap Pemodelan Knowledge Capture

Kerangka penyelesaian masalah yang digambarkan dengan flow chart pada Gbr 1. Langkah-langkah penyelesaian masalah dibagi menjadi dua proses utama yaitu proses analisis dan proses pemodelan knowledge capture yang merupakan goal dalam penelitian ini. Pada Gbr 1, setelah memulai penelitian maka dilakukan observasi di lingkungan SMA Kristen Tobelo Kab. Halmahera Utara untuk melihat secara langsung semua aktifitas, kegiatan dan aktor-aktor yang terlibat dan berkaitan dengan permasalahan yang akan diteliti. Selanjutnya dilakukan pengidentifikasian terhadap permasalahan yang akan diteliti dan teridentifikasi permasalahan SMA Kristen Tobelo Kab. Halmahera Utara adalah banyaknya siswa terlambat ke sekolah dan pengetahuan tacit dari para guru yang menanganinya perlu di"tangkap" (capture).

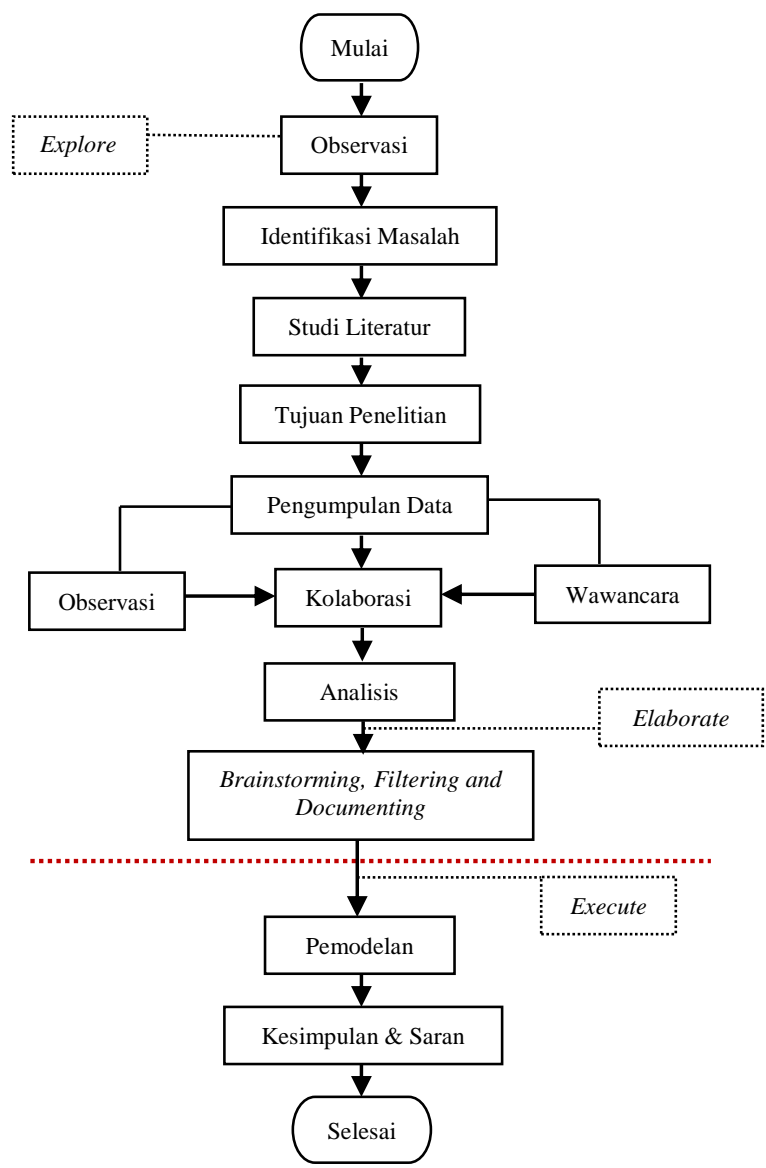

Gbr. 1 Kerangka Penyelesaian Masalah

Terkait tujuan penangkapan pengetahuan ini maka sebelumnya dilakukan studi literatur sebagai dasar untuk memperoleh referensi-referensi agar penelitian dapat dipertanggung jawabkan secara ilmiah. Pengumpulan data dilakaukan dengan cara observasi ke sekolah dan melakukan wawancara kepada guru dan siswa untuk memperoleh knowledge tentang siswa terlambat. Data-data yang telah diperoleh ini kemudian dikolaborasikan untuk memperoleh informasi tentang penyebab siswa datang terlambat dengan cara brainstorming, filtering and Documenting. Hasil perbandingan berupa informasi yang telah terdokumentasi kemudian dianalisis dan dibuat model knowledge capture untuk SMA Kristen Tobelo Kab. Halmahera Utara.

\section{B. Gambaran Situasi Penelitian}

Penelitian yang dilakukan bertempat di SMA Kristen Tobelo Kab. Halmahera Utara pada bagian kesiswaan yang berlokasi di Jln. R.S Bethesda Kecamatan Tobelo, Kabupaten Halmahera Utara. Berada di tengah kota Kabupaten membuat sekolah ini mudah ditemukan dari segi jalur transportasi. Penelitian diawali dengan cara wawancara terhadap beberapa siswa dan guru yang menangani siswa terlambat. Diperoleh informasi 406 siswa yang terbagi ke dalam 16 kelas yang terdiri dari 6 kelas untuk kelas X, 5 kelas untuk kelas XI dan 5 kelas untuk kelas XII, rata-rata jumlah siswa terlambat per hari 20 siswa, pada hari-hari tertentu bisa mencapai 30 sampai 40 siswa terlambat, tentang peran guru, cara penanganan dan 
penyebab siswa terlambat. Selanjutnya diekspresikan situasi dalam bentuk gambar seperti yang digambarkan dalam Gbr 2 .

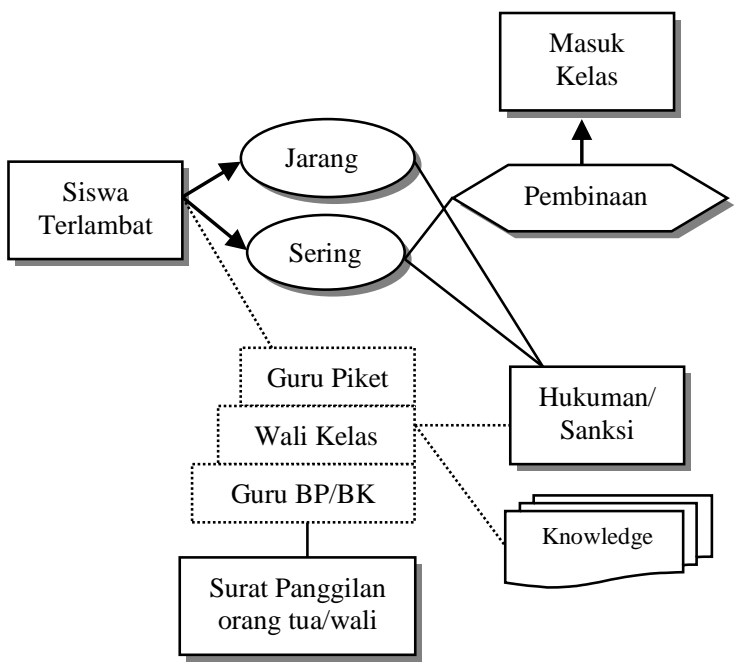

Gbr. 2 Situasi Penelitian

Untuk mendapatkan data selain dari hasil observasi dan wawancara, juga didapat dari bagian kesiswaan sekolah. Dalam penelitian ini didapati siswa jarang terlambat dan sering terlambat. Ketika siswa jarang terlambat dan sering terlambat melakukan pelanggaran dengan cara datang terlambat ke sekolah maka keduanya akan mendapat hukuman/sanksi dan juga pembinaan di tempat yang diberikan oleh guru piket yang bertugas, kemudian masuk ke kelas. Lain halnya dengan siswa yang sering terlambat, akan mendapat hukuman/sanksi dan pembinaan yang lebih supaya tidak terlambat lagi ke sekolah. Penanganannya dimulai dari guru piket dilanjutkan ke wali kelas dan menurut salah seorang guru mengatakan bahwa pengalaman yang terjadi hanya sampai ke tingkat penanganan wali kelas, siswa sering terlambat sudah bisa ditangani. Tetapi ada juga kejadian beberapa siswa yang harus sampai ke penanganan guru $\mathrm{BP} / \mathrm{BK}$. Jika masih belum berhasil dengan siswa sering terlambat ini maka akan dipanggil orang tua/wali siswa tersebut.

Untuk mengurangi jumlah siswa terlambat masih belum memberi dampak baik karena hanya berupa pembinaan. Pernah berdampak signifikan dilakukan dengan cara memukul, tetapi hanya beberapa hari saja dan setelah itu kembali ke kondisi semula. Ini menunjukan bahwa siswa hanya taat karena dipukul bukan karena kesadaran diri terhadap peraturan yang telah dibuat sekolah.

\section{HASIL DAN PEMBAHASAN}

Data dilapangan menunjukan ada berbagai macam alasan yang diberikan siswa saat terlambat dan tindak penangan yang dilakukan guru terhadap siswa terlambat. Data tersebut didapat dari guru dan siswa dengan cara observasi dan wawancara. Hasil wawancara yang dilakukan terhadap tujuh orang guru diperlihatkan pada Tabel I.

Setelah melakukan wawancara dengan guru, selanjutnya dilakukan wawancara dengan siswa. Wawancara dilakukan dengan sepuluh siswa dan rekapan hasil wawancara diperlihatkan pad Tabel II.
TABEL I

HASIL WAWANCARA GURU

\begin{tabular}{|c|c|}
\hline \multicolumn{2}{|r|}{ Apa Alasan Siswa Datang Terlambat? } \\
\hline Guru 1 & $\begin{array}{l}\text { Bangun kesiangan, Sakit perut, Susah } \\
\text { kendaraan, Pakaian basah }\end{array}$ \\
\hline Guru 2 & $\begin{array}{l}\text { Susah kendaraan, Bangun kesiangan, hujan, } \\
\text { Rumah jauh (Dispensasi), Tidak ada peralatan } \\
\text { belajar }\end{array}$ \\
\hline Guru 3 & $\begin{array}{l}\text { Bangun kesiangan (Kerja tugas), transportasi } \\
\text { (jarak ke sekolah), jemput teman, sakit perut }\end{array}$ \\
\hline Guru 4 & $\begin{array}{l}\text { Bangun kesiangan, masalah di jalan (mogok- } \\
\text { ban bocor), tempat tinggal jauh, kerja tugas } \\
\text { sampai larut malam, baju basah }\end{array}$ \\
\hline Guru 5 & $\begin{array}{l}\text { Tinggal dengan wali, selesaiakan pekerjaan di } \\
\text { rumah (menyapu-cuci peralatan makan dll), } \\
\text { jarak ke sekolah }\end{array}$ \\
\hline Guru 6 & $\begin{array}{l}\text { Susah kendaraan, Tempat tinggal jauh, bangun } \\
\text { kesiangan, Kerja tugas sampai larut malam }\end{array}$ \\
\hline Guru 7 & $\begin{array}{l}\text { Bangun kesiangan, hujan, membantu pekerjaan } \\
\text { dirumah, susah kendaraan }\end{array}$ \\
\hline \multicolumn{2}{|r|}{ Apa Hukuman/Sanksi Bagi Siswa Terlambat? } \\
\hline Guru 1 & $\begin{array}{l}\text { Angkat sampah, Lari } 5 \text { putaran lapangan } \\
\text { sekolah, bersihkan WC }\end{array}$ \\
\hline Guru 2 & $\begin{array}{l}\text { Bersihkan halaman, pembinaan langsung } \\
\text { ditempat, menuliskan "saya tidak akan } \\
\text { terlambat lagi" sebanyak } 100 \text { kali }\end{array}$ \\
\hline Guru 3 & Angkat sampah, dijemur, pembinaan di tempat. \\
\hline Guru 4 & $\begin{array}{l}\text { Lari keliling lapangan, Angkat sampah, } \\
\text { bersihkan kamar mandi, dijemur, tidak bisa ikut } \\
\text { jam pelajaran pertama (di perpustakaan) }\end{array}$ \\
\hline Guru 5 & Bersihkan kaca, bersihkan WC, rumah jauh \\
\hline Guru 6 & $\begin{array}{l}\text { Angkat sampah, bersihkan WC, menyapu } \\
\text { lingkungan sekolah }\end{array}$ \\
\hline Guru 7 & aan, angkat samp \\
\hline
\end{tabular}

TABEL II

HASIL WAWANCARA SISWA

\begin{tabular}{|l}
\multicolumn{1}{c}{ Alasan Terlambat? } \\
\hline - Bangun kesiangan \\
- Tempat tinggal jauh \\
- Membersihkan/menyelesaiakan tugas rumah \\
- Transportasi
\end{tabular}

\section{Apa Penyebabnya?}

- Menonton TV sampai larut malam

- Main dengan teman/Keluyuran malam

- Main HP sampai larut malam (Media Sosial, Game)

- Susah angkutan umum

- Mengerjakan tugas sekolah

Berdasarkan hasil wawancara diatas, selanjutnya dilakukan analisis akibat, alasan dan kondisi terhadap hasil wawancara tersebut. 


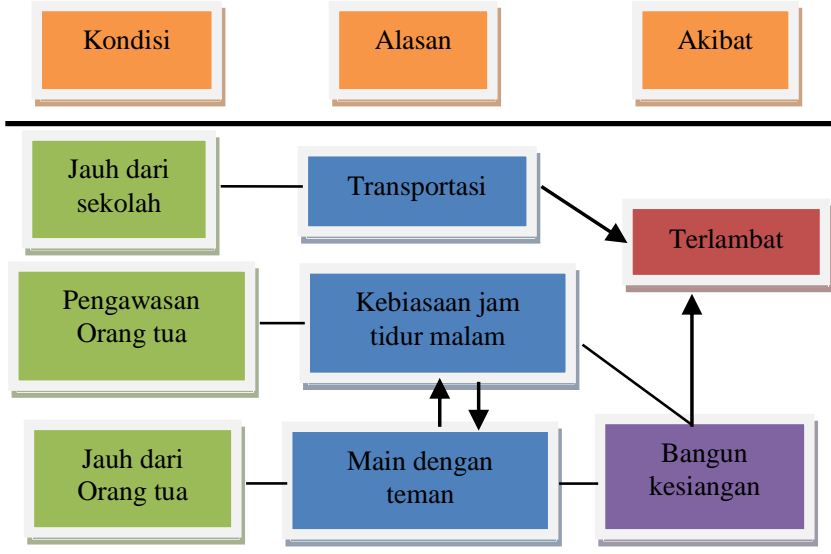

Gbr. 3 Skema Analisis Masalah

Bangun kesiangan menjadi alasan yang paling banyak diberikan siswa ke guru pada saat mereka terlambat. Alasan ini sering ditemukan pada siswa yang tinggal dekat dengan sekolah. Ketika siswa terlambat dan memberikan alasan ini, yang menjadi pertanyaan adalah kenapa bangun kesiangan? Apa yang dilakukan pada malam harinya? Apa yang dilakukan sebelum datang ke sekolah?. Beberapa siswa tidak tinggal dengan orang tua tetapi dengan orang tua wali dan beberapa menyewa kamar kost. Sebagai orang tua atau orang tua wali harusnya ada kepedulian terhadap anak dengan mengawasi jam tidur malam anaknya serta memperbiasakan untuk bangun pagi.

Jarak yang jauh dari rumah ke sekolah juga menjadi alasan siswa mengapa mereka terlambat. Hal ini berkaitan dengan transportasi yang mereka gunakan untuk sampai ke sekolah yaitu angkutan umum yang masih jarang dari desa mereka. Keterlambatan mereka juga disebabkan karena angukutan umum yang digunakan harus menunggu penumpang yang hendak ke kota, berjualan ke pasar diwaktu pagi.

\section{A. Explore (Eksplorasi)}

Proses eksplorasi dengan cara observasi dan wawancara yang telah dilakukan di SMA Kristen Tobelo Kab. Halmahera utara menunjukan banyaknya jumlah siswa terlambat ke sekolah. Pengetahuan yang ditangkap berupa alasan dan penyebab keterlambatan siswa ini bermacam-macam. Berikut digambarkan pada Gambar 4.

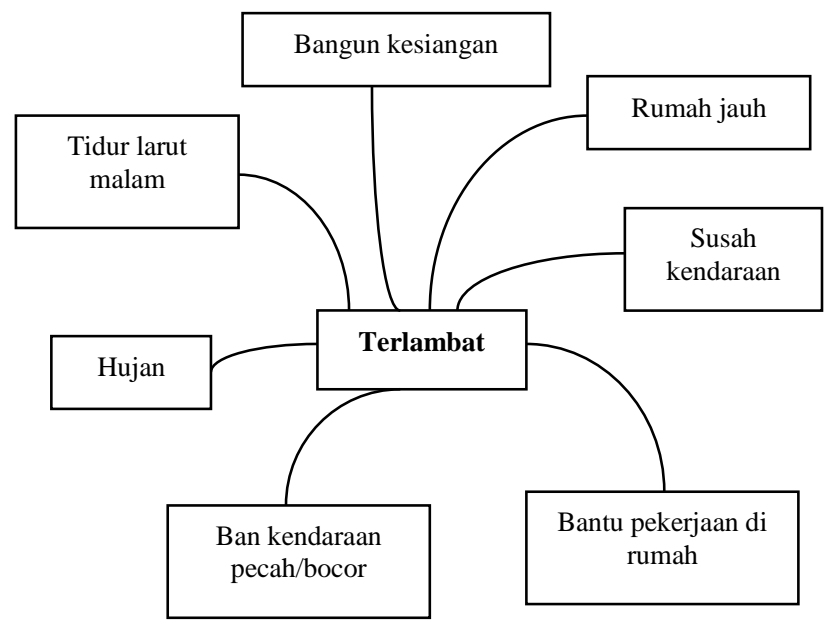

Gbr. 4 Alasan dan penyebab siswa terlambat
Selalu adanya siswa yang terlambat datang ke sekolah setiap hari telah menjadi pemandangan umum. Siswa terlambat datang ke sekolah berlanjut pada keterlambatan masuk kelas yang berpengaruh terhadap kelancaran proses kegiatan belajar mengajar saat jam pertama pelajaran. Keterlambatan siswa bukan tanpa sebab. Terdapat beberapa faktor yang menyebabkan keterlambatan siswa seperti faktor diri sendiri (pribadi), faktor keluarga dan faktor lingkungan, dengan alasan bangun kesiangan, tempat tinggal jauh dari sekolah, dan transportasi. Apapun alasan yang menjadi faktor keterlambatan siswa ini menunjukan tingkat kedisiplinan yang masih rendah dan tidak boleh dibiarkan karena bisa membudaya buruk pada lembaga sekolah.

Pendokumentasian siswa-siswa terlambat masih bersifat manual karena masih dicatat dalam selembar kertas dengan format yang telah ditentukan. Format tersebut berisi namanama siswa per kelas yang kemudian diberi tanda centang jika siswa terlambat. Kertas tersebut kemudian diserahkan ke masing-masing wali kelas untuk ditindak lanjuti dan diteruskan ke bagian kesiswaan sebagai bahan rekapan di akhir semester.

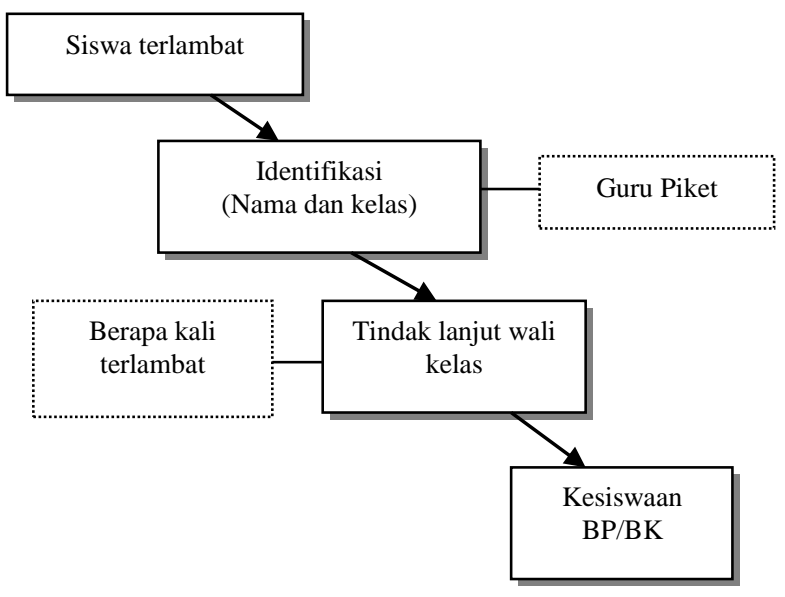

Gbr. 5 Pendokumentasian siswa terlambat

Pendokumentasian penanganan seperti ini telah menciptakan pengetahuan yang masih bersifat tacit yang kemudian di-explicit-kan. Berikut adalah pengetahuan yang dimiliki oleh guru-guru.

TABEL III

PENGETAHUAN TACIT

\begin{tabular}{|c|l|}
\hline Aktor & \multicolumn{1}{|c|}{ Pengetahuan } \\
\hline Guru Piket & $\begin{array}{l}\text { Alasan siswa terlambat, tempat tinggal } \\
\text { siswa (desa asal),sanksi yang diberikan, } \\
\text { materi pembinaan }\end{array}$ \\
\hline Wali Kelas & $\begin{array}{l}\text { Materi pembinaan, tempat tinggal siswa } \\
\text { (desa asal), latar belakang siswa }\end{array}$ \\
\hline $\begin{array}{c}\text { Kesiswaan } \\
(\mathrm{BP} / \mathrm{BK})\end{array}$ & $\begin{array}{l}\text { Kelas yang paling banyak terlambat, } \\
\text { Rakapan data siswa terlambat, strategi } \\
\text { pengelolaan siswa terlambat }\end{array}$ \\
\hline
\end{tabular}




\section{B. Elaborate (Elaborasi)}

Sesuai dengan penjabaran kerangka penyelesaian masalah, di tahapan elaborasi terdapat empat poin utama yang harus dilakukan yaitu kolaborasi data observasi dan wawancara, brainstorming, filtering dan documenting. Kolaborasi antara data hasil observasi dan wawancara menghasilkan materi pembahasan permasalahan. Dengan kata lain disebutkan bahwa materi yang dihasilkan merupakan hasil eksplorasi.

Proses elaborasi diawali dengan penyusunan materi berdasarkan hasil eksplorasi. Materi yang disusun berisikan tentang permasalahan yang sedang dihadapi, mengapa sampai munculnya permasalahan, data-data lapangan dan penentuan jalan keluar permasalahan. Masalah yang dihadapi disini adalah tentang kedisiplinan siswa dalam hal ini mengenai banyaknya siswa yang terlambat ke sekolah. Mengapa sampai terjadi hal ini karena disebabkan beberapa faktor seperti faktor pribadi (malas), faktor keluarga (pengawasan orang tua) dan faktor lingkungan (jarak rumah ke sekolah). Penjelasan tahap elaborasi digambarkan pada Gambar 6.

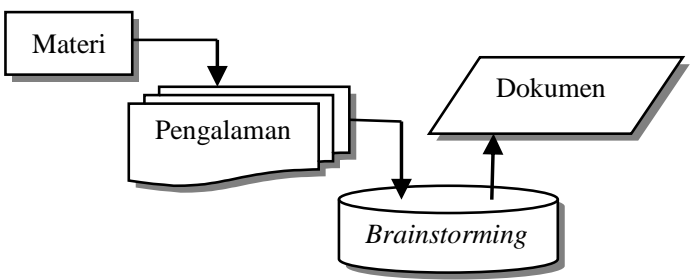

Gbr. 6 Proses Elaborasi

Setelah ada materi, dilakukan curah pendapat (brainstorming) terhadap guru-guru yang selama ini menangani kasus keterlambatan siswa, pengetahuan serta pengalaman apa saja yang dimiliki sesuai dengan materi. Pengetahuan dan pengalaman seseorang biasanya masih bersifat tacit dan sulit untuk dibagikan. Perbedaan cara pandang tentang brainstorming atau knowledge sharing berkaitan denga faktor psikologis dan sosiologis yang mebuat kecenderungan individu untuk berbagi pengetahuan [13]. Pengetahuan dan pengalaman tersebut sulit untuk dibagikan karena dilakukan dengan cara yang tidak tepat [14]. Salah satu cara yang digunakan untuk mengeksplisitkan tacit adalah dengan cara brainstorming. Gambaran proses yang dilakukan pada tahap brainstorming digambarkan pada Gambar 7 .

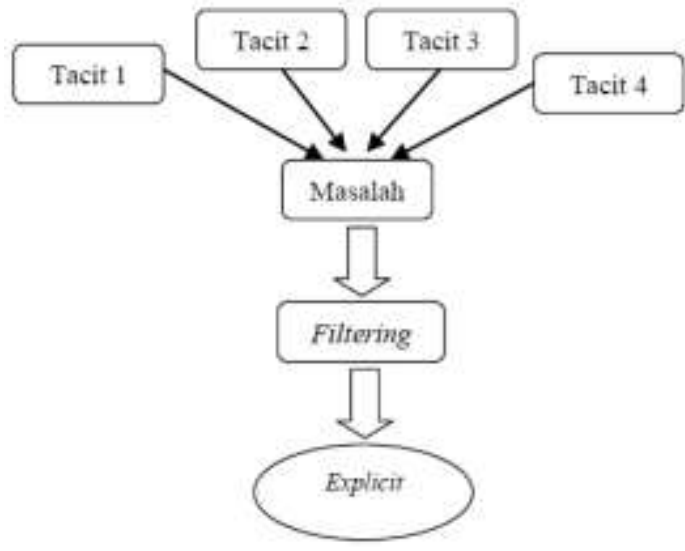

Gbr. 7 Proses brainstorming
Pada proses brainstorming, yang dilakukan adalah usaha untuk mengeluarkan dan mendokumentasikan semua tacit yang berhubungan dengan masalah dan kebutuhan materi yang dimiliki masing-masing orang. Dokumentasi hasil brainstorming kemudian disaring dan dipilih, tacit mana yang berkaitan erat dengan penyelesaian masalah dan sesuai dengan kebutuhan materi. Setelah selesai disaring, maka telah didapati explicit knowledge dari masing-masing sumber tacit.

TABEL IV

HASIL BRAINSTORMING

\begin{tabular}{|c|l|}
\hline Masalah & \multicolumn{1}{|c|}{ Pengetahuan } \\
\hline \multirow{5}{*}{$\begin{array}{c}\text { Siswa } \\
\text { Terlambat }\end{array}$} & $\begin{array}{l}\text { Siswa sudah tiba di lokasi sekolah kemudian } \\
\text { pergi ke rumah teman yang dekat sekolah } \\
\text { barulah bersama-sama ke sekolah }\end{array}$ \\
\cline { 2 - 2 } & $\begin{array}{l}\text { Siswa disuruh menyelesaiakan pekerjaan di } \\
\text { rumah (menyuci piring, menyapu halaman } \\
\text { dll) baru bisa ke sekolah }\end{array}$ \\
\cline { 2 - 2 } & $\begin{array}{l}\text { Orang tua yang terlalu sibuk dengan } \\
\text { pekerjaan mengabaikan pengawasan } \\
\text { terhadap kedisiplinan anaknya }\end{array}$ \\
\cline { 2 - 2 } & $\begin{array}{l}\text { Siswa terlambat karena tinggal jauh dari } \\
\text { sekolah (harus menyeberangi laut sekitar 10 } \\
\text { menit) kemudian menunggu angkutan umum } \\
\text { ke sekolah }\end{array}$ \\
\cline { 2 - 2 } & $\begin{array}{l}\text { Siswa mengikuti guru karena guru juga } \\
\text { terlambat }\end{array}$ \\
\cline { 2 - 2 } & $\begin{array}{l}\text { Mencari tempat tinggal yang lebih dekat ke } \\
\text { sekolah tapi siswa tidak mau dengan alasan } \\
\text { tidak ada keluarga dan butuh tambahan biaya } \\
\text { bila harus menyewa kamar kost }\end{array}$ \\
\hline
\end{tabular}

Hasil dari curah pendapat yang merupakan explicit data dari masing-masing tacit disimpan dalam bentuk dokumen pengetahuan. Proses brainstorming menghasilkan sebuah pengetahuan explicit berupa dokumen pengetahuan yang berisi rumusan masalah bagaimana untuk mendisiplinkan siswa-siswa, strategi apa yang digunakan agar siswa tidak terlambat ke sekolah

\section{Execute (Eksekusi)}

Setelah melalui proses elaborate, langkah selanjutnya adalah pelaksanaan hasil elaborate. Bagian ketiga dari tiga bagian utama pembahasan sesuai metode adalah execute yang akan menerapkan hasil elaborate. Proses atau alur pelaksanaannya digambarkan pada Gambar 8 .

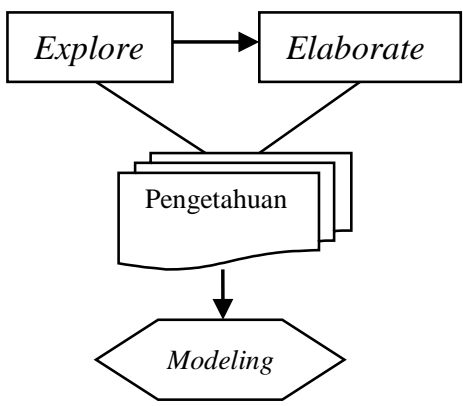

Gbr. 8 Proses Eksekusi 
Proses eksekusi merupakan tahap akhir dari tiga teknik penangkapan pengetahuan yang digunakan dalam penelitian ini. Sesuai dengan metode, pada tahap ini dilakukan pemodelan penangkapan pengetahuan. Pemodelan penangkapan pengetahuan dibuat berdasarkan tahap explore dan elaborate yang telah menghasilkan explicit pengetahuan para aktor.

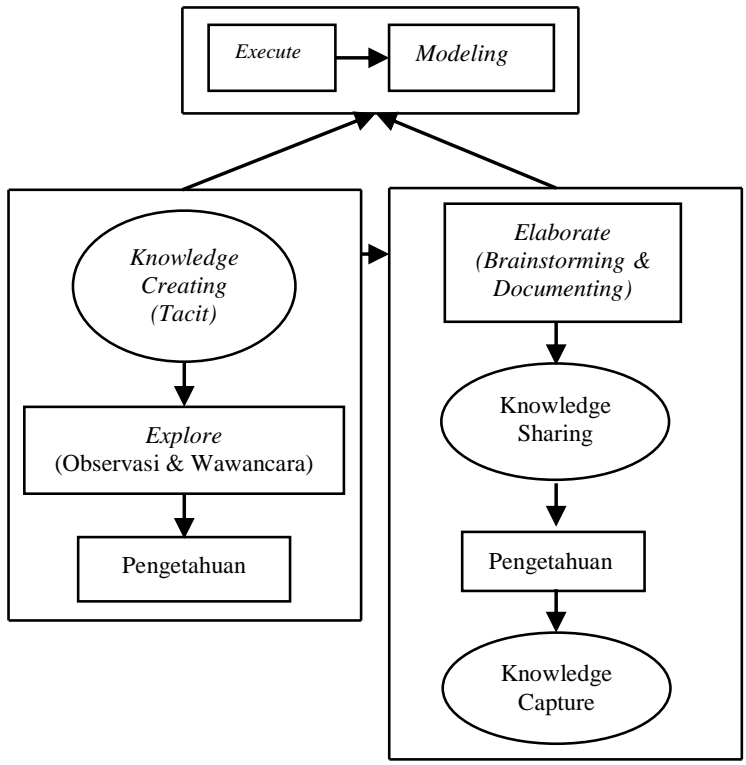

Gbr. 9 Proses Modeling

\section{Model Knowledge Capture}

Sekolah dalam melaksanakan kegiatannya terdapat beberapa permasalahan salah satunya adalah siswa terlambat. Sesuai dengan metode yang diterapkan bahwa dalam menyelesaikan permasalahan ini, dilakukan dengan menangkap pengetahuan yang berkaitan dengan penanganan siswa terlambat menggunakan teknik explore, elaborate dan execute. Dalam menangani siswa terlambat terbentuklah Knowledge Creating. Penangkapan pengetahuan dimulai dengan teknik explore untuk mencari tahu penyebab siswa terlambat dan pengetahuan yang dimiliki selama proses penanganan siswa terlambat. Selama proses tersebut pastinya telah tercipta pengetahuan yang belum terstruktur dan masih bersifat tacit. Untuk menambah pengetahuan dalam organisasi ada baiknya pengetahuan yang telah ada didokumentasikan dan disimpan. Supaya lebih terstruktur, pengetahuan harus dibagikan maka dilakukan teknik elaborate melalui knowledge sharing untuk mengumpulkan semua tacit, menyaring dan membuatnya lebih terstruktur dan terdokumentasi. Hasil elaborate (knowledge capture) disimpan dalam repository dan dengan bantuan teknologi untuk membantu pengolahan knowledge. Tangkapan pengetahuan dalam bentuk document knowledge dapat memperkaya pengetahuan organisasi dan membantu sekolah dalam kegiatannya sebagai lembaga pendidikan yang mengajarkan kedisiplinan.

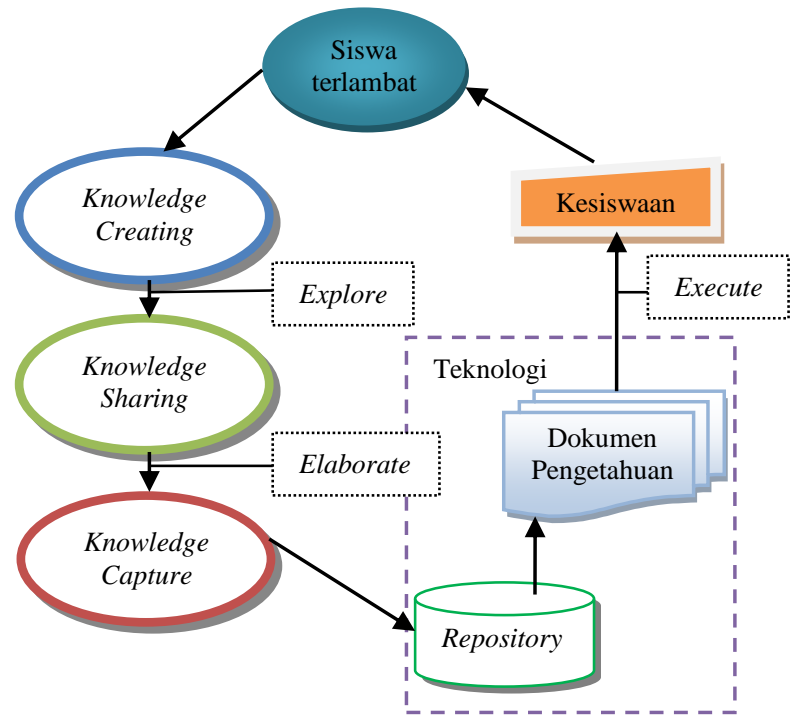

Gbr. 10 Model Knowledge Capture

\section{E. Implementasi}

Ketika diperhadapkan dengan kasus siswa terlambat, selain diberikan sanksi keterlambatan kepada siswa, guru juga harus tahu penyebab hingga siswa tersebut terlambat. Penyebab keterlambatan yang diberikan siswa inilah yang menjadi tacit bagi guru yang nantinya akan dielaborasikan dalam permasalahan siswa terlambat. Selain menjadi tacit guru secara individu, ini juga menjadi kekayaan pengetahuan dalam organisasi sekolah karena guru berada dalam lingkungan organisasi sekolah.

Pengetahuan individu dan organisasi tidak terlepas hubungannya dengan document knowledge yang telah dimiliki sekolah sebagai acuan kelola permasalahan siswa terlambat. Document knowledge digunakan sebagai tambahan pengetahuan dalam menelaah masalah yang adalah hasil dari proses elaborasi. Pengetahuan yang masih bersifat tacit kemudian dirumuskan, dicari jalan keluar untuk pemberian sanksi terlambat dan juga tindakan apa yang harus dilakukan kepada siswa tersebut untuk tidak lagi terlambat datang ke sekolah.

Tindakan yang telah dilakukan dicatat dan dilaporkan sebagai bahan evaluasi agar mendapat tanggapan yang nantinya kembali menjadi tambahan pengetahuan baru untuk individu dan organisasi.



Gbr. 11 Skema Implementasi 
Penanganan siswa terlambat telah tercipta pengetahuan (knowledge creating). Pengetahuan yang tercipta ini belum terstruktur, didapat dari pengalaman-pengalaman atau keahlian pribadi dan masih bersifat tacit (terdapat dalam otak/pikiran). Langkah eksplorasi yang dilakukan menunjukan adanya pengalaman-pengalaman yang masih tersimpan dalam pikiran individu. Supaya pengetahuanpengetahuan yang dimiliki ini bisa dieksplisitkan, dilakukan teknik elaborasi untuk mengadakan knowledge sharing agar pengetahuan yang dimiliki bisa diungkapkan/ditransfer melalui percakapan. Langkah eksplorasi dan elaborasi merupakan cara untuk menangkap pengetahuan (knowledge capture) yang dimiliki oleh guru dan siswa.

Eksplorasi yang dilakukan telah berhasil menemukan dan mengungkapkan pengetahuan-pengetahuan yang dimiliki oleh guru-guru dan para siswa dengan cara observasi dan wawancara yang telah dijelaskan pada pembahasan eksplorasi diatas. Ini membuktikan bahwa dalam menangani siswa terlambat telah tercipta dan tersimpan pengetahuan.

Proses elaborasi untuk mengeksplisitkan tacit agar terdokumentasi. Organisasi harus hati-hati dalam mengubah aspek pengetahuan tacit menjadi pengetahuan explicit. Jika tidak, maka pengetahuan tacit yang dimiliki mungkin saja hilang. Ini sangat penting dalam proses manajemen pengetahuan karena mengacu pada transfer pengetahuan pada tempat yang sesuai [15]. Elaborasi dilakukan untuk menyatukan pengetahuan, menyaring dan menangkap pengetahuan melalui curah pendapat (brainstorming). Setelah melalui tahap elaborasi maka hasil elaborasi tersebut telah sedia untuk dieksekusi menjawab permasalahan yang terjadi.

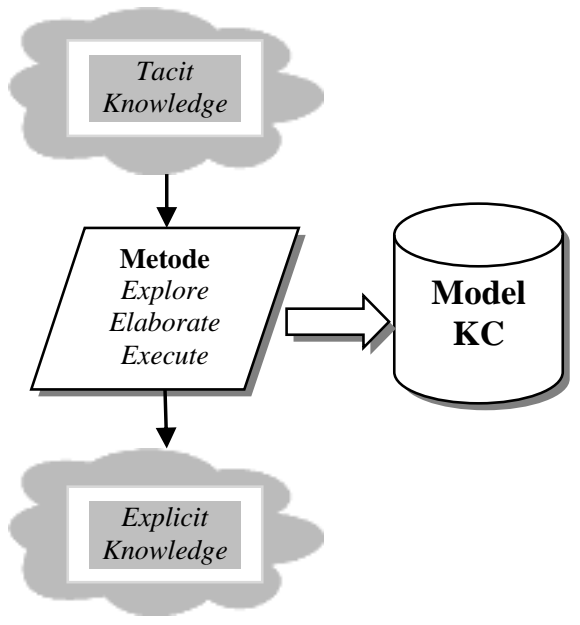

Gbr. 12 Implementasi Model

\section{F. Hasil Pengujian}

Eksekusi yang telah dilakukan tidak berhenti sampai disitu saja tetapi diamati untuk dievaluasi kembali apakah efektif, adakah kekurangan dan adakah pengetahuan baru yang tercipta. Pengujian dilakukan untuk mencari tahu sejauh mana progres dari tindakan yang telah dilakukan dan untuk menemukan tanggapan dari anggota dalam organisasi. Dengan demikian hasil pengujian bisa menjadi tambahan pengetahuan kepada masing-masing individu atau kekayaan pengetahuan organisasi.
Hasil pengujian menunjukan pencapaian yang belum maksimal dalam penggunaan teknologi dari cara pengolahan dan pendokumentasian data siswa terlambat maupun cara pendokumentasian pengetahuan. Ini memberi peluang untuk melakukan penelitian selanjutnya untuk membuat Knowledge Base memanfaatkan teknologi. Dengan demikian, tanpa melakukan eksplorasi sudah bisa ditemukan pengetahuanpengetahuan guru selama menangani kasus siswa terlambat. Cara pendokumentasian pengetahuan dengan memanfaatkan teknologi belum ada sama sekali. Data siswa terlambat hanya sebatas pencatatan di kertas biasa dengan format yang telah ditentukan, belum ada tampilan berupa tabel atau grafik. Data tersebut hanya dikumpulkan dan disimpan yang kemudian direkap pada akhir semester pada saat penerimaan raport. Berdasarkan model penangkapan pengetahuan dan hasil pengujian, diusulkan untuk tidak hanya menampilkan dan mengetahui data angka saja tetapi juga pengetahuan deskriptif sehingga lebih memperkaya pengetahuan organisasi sekolah.

\section{KESIMPULAN}

Dalam menangani dan mengelola kasus keterlambatan siswa, guru telah banyak memperoleh pengetahuan (knowledge creating) dan berbagi pengetahuan bersama (knowledge sharing) dalam organisasi sekolah melalui rapat evaluasi tapi belum ada kesadaran untuk menangkap pengetahuan (knowledge capture). Berdasarkan hasil dan pembahasan yang telah dilakukan tentang penangkapan pengetahuan dalam kasus keterlambatan siswa untuk bagian kesiswaan sekolah telah berhasil memodelkan sebuah model knowledge capture dengan menggunakan teknik explore, elaborate and execute. Pemodelan knowledge capture yang dihasilkan telah menggambarkan situasi permasalahan, proses penangkapan pengetahuan, proses penyatuan pengetahuan serta proses penerapannya. Adanya penelitian ini telah mengungkapkan pengetahuan yang selama ini hanya menjadi kekayaan pengetahuan pribadi guru menjadi kekayaan pengetahuan organisasi sekolah dalam menyusun strategi untuk mengurangi kasus siswa terlambat.

Dengan memanfaatkan teknologi, harusnya lebih baik dalam menjalankan proses-proses ini tetapi belum dimanfaatkan secara baik. Terlihat dari belum adanya media penangkapan pengetahuan berbasis teknologi. Ini memungkinkan adanya penelitian selanjutnya untuk mendesain sebuah interface pemanfaatan teknologi dalam proses penangkapan pengetahuan. Sehingga, penelitian ini menjadi motivasi pihak sekolah dalam memanfaatkan teknologi sepenuhnya untuk penangkapan pengetahuan.

\section{DAFTAR PUSTAKA}

[1] Undang-Undang Republik Indonesia Nomor 20 Tahun 2003 Tentang Sistem Pendidikan Indonesia.

[2] F. J. Fiana, Daharnis, and M. Ridha, "Disiplin Siswa di Sekolah dan Implikasinya dalam Pelayanan Bimbingan dan Konselin," Konselor, vol. 2, no. 23, pp. 26-33, April 2013.

[3] D. Mulyani, "Hubungan Kesiapan Belajar Siswa Dengan Prestasi Belajar," Konselor, vol. 2, no. 1, pp. 27-31, Januari 2013.

[4] M. B. Rober and L. P. Cooper, "Capturing Knowledge via an Intrapedia: A Case Study," in 2011 IEEE 44th Hawai International Conference on System Science, 2011.

[5] D. Anagnostakis, J. Ritchie, T. Lim, A. Sivanathan, R. Dewar, R. Sung, F. Bosche and L. Carroza, "Knowledge capture in CMM 
Inspection Planning: barriers and challenges," Procedia CIRP, No. 52, pp. 216-221, 2016

[6] D. Mourtzis and M. Doukas, "Knowledge Capturing and Reuse to Support Manufacturing of Customised Products: A case study from the mould making industry," Procedia CIRP, No. 21, pp. 123-128, 2014.

[7] T. S. Nicolas Rocca and J. L. Parrish Jr, "Capturing and Conveying Chamorro Cultural Knowledge Using Social Media," International Journal of Knowledge Management, vol. 9, no. 3, pp. 1-18, JuliSeptember 2013.

[8] N. N. Aming'a, "Knowledge Capture and Acquisition Mechanisms at Kisii University," Interdisciplinary Journal of Information, Knowledge and Management, vol. 10, pp. 105-116, Juli 2015.

[9] D. I. Sensuse and Lukman, "Knowledge Management Model and Strategy of Genetic Resources and Traditional Knowledge in Indonesia," International Journal of Computer Science Issue, vol. 9, no. 2, pp. 480-488, Maret 2012.

[10] A. Desai and S. Rai, "Knowledge Management for Downstream Supplay Chain Management of Indian Public Sector Oil Companies,"
2016 7th International Conference on Communication, Computing and Virtualization, no. 79, pp. 1021-1028, 2016.

[11] W. G. Dzekashu and W. R. McCollum, "A Quality Approach to Tacit Knowledge Capture: Effective Practice to Achieving Operational Excellence," International Journal of Applied Management and Technology, vol. 13. no. 1, pp. 52-63, 2014.

[12] Kamus Besar Bahasa Indonesia [Online]. Available: http://kbbi.web.id. [Accessed: 22-Mar-2018].

[13] D. Paulin and K. Suneson, "Knowledge Transfer, Knowledge Sharing and Knowledge Barriers - Three Blurry Terms in KM," The Electronic Journal of Knowledge Management, vol. 10. No. 1, pp. 81-91, 2012

[14] M. Barwick, "Buiding Scientist Capacity in Knowledge Translation Development of the Knowledge Translation Planning Template," Technology Innovation Management Review, vol. 6, no. 9, pp. 9-15, September 2016.

[15] C. L. H. Chang and T. C. Lin, "The Role of Organizational Culture in The Knowledge Management Process," Journal of Knowledge Management, vol. 19. No. 3, pp. 433-455, 2015. 